\title{
13
}

\section{Conclusion: The Residual Spirituality in Critical Theory: A Case for Affirmative Postsecular Politics}

\author{
Rosi Braidotti
}

\section{Introduction}

The highly politicized context in which issues linked to religion in the public sphere are being discussed, in Europe and elsewhere in the world today, raises a number of questions that go beyond the study of religion itself. Throughout this volume, the issue of the postsecular has been addressed as one of the defining features of the material and discursive conditions that structure our social context. The starting assumption for this volume was the determination to disrupt the dominant equation between Christianity and secularism, so as to open up new spaces for critical theory. Stathis Gourgouris put it admirably: 'the ultimate point is not merely to disrupt the antinomic complicity between the religious and the secular, but to take away from the religious the agency of determining what is secular' (Gourgouris, 2013: 62).

While the general focus of this volume is on this particular challenge, the contributors have been encouraged to roam freely and address this issue from a range of transdisciplinary fields and methods. In this process, they have constructed several relevant and multifaceted intersections of the postsecular condition.

The nodal points of the book are: firstly, the manipulative framing of debates on secularism by conservative and populist political forces in the European Union today, in terms of the cultural and philosophical legacy of Christianity and the Western project of modernity (Hemel; Sørensen; Lentin and Titley); secondly, the repercussions of these political and social movements for the terminology and the agenda of contemporary philosophical debates (Lambert; Baumgartner; Egginton; Braidotti); and 
thirdly, the implications of this politically loaded context for the status of women and LGBT people (Midden; Korte) and for contemporary neoand postcolonial geopolitical relations, including their socio-economic and technological aspects (Eisenlohr; Klassen; Leurs and Ponzanesi).

These are not merely single and isolated thematic cross references; they compose a multi-dimensional web of dynamically linked social and discursive effects. The volume does not aim to provide even a synoptic view, let alone a synthesis, of these complex phenomena. What we have attempted instead is a cartographic account of their multiple and subtle resonances and of their mutual reinforcement through the reiteration of common themes, tropes, and concerns. The shared belief in the materiality of a complex historical event we call 'the postsecular predicament' therefore does not detract from, but rather constitutes, the core of this volume's theoretical complexity. As the essays gathered here clearly demonstrate, whatever the postsecular predicament may or may not be - and the positions on this question differ considerably - it nonetheless touches some raw nerves in the theory and practice of critical thought. The volume focuses on the strength and relevance of the postsecular moment and its impact upon ethical and political citizenship in the twenty-first century. The authors propose a range of critical responses and political reactions to the web of complex social relations that constitute 'the postsecular predicament' and thus contribute to a more sharply defined and socially responsible agenda on this issue. In this volume, the political critique of a Eurocentric and Western supremacist ideology of coercive secularism - as intrinsically linked to religion by negation - works in tandem with a rigorous scientific investigation of the renewed vitality of the theme of religion in the public sphere. In this intense collective endeavour, critique and creativity reinforce and co-define each other.

Given that the volume deals so extensively with the complex and multi-layered phenomenon that is the postsecular predicament, far from attempting to resolve or dissolve this complexity, I think the next step needs to take the argument further by connecting it to the issue of postsecular subjectivity. The key question I want to discuss consequently is: how does the project of critical theory and the ethical drive that sustains it relate to the postsecular predicament? What kind of subject need one be, in order to actively desire to undertake the demands and expectations of critical theory in a postsecular context? I do not mean to refer back to moral intentionality or rational choice, but rather to explore and deploy the question affectively and ethically in terms of processoriented nomadic subjectivity. 
My starting assumption is twofold: firstly, there is a strong sense of socio-political urgency about the postsecular predicament. Secondly, this complex phenomenon constitutes the backdrop against which I want to defend an affirmative politics, resting on a vital materialist vision of subjectivity. It is precisely because they touch such raw nerves in people's sense of identity and identification that critical theories of the subject are so important in a postsecular age. Contemporary subjects have to confront the complex challenges of living in a fast-changing, globally interlinked, technologically mediated world. We need to let go of the familiar while resisting the pull of fear, anxiety, and nostalgia that come with departing from set habits and known mental landscapes. We need to learn to think differently about what kind of subjects we are in the process of becoming.

In this postface, I will take the unusual step of developing a personal position on the issue of the residual spirituality of critical theory through the analysis of postsecular subjectivity. I want to argue for a vision of consciousness that links thinking to affectivity, critique to affirmation instead of negativity, and that does not hesitate to show traces of residual - albeit it non-theistic - spirituality. The conceptual punch of something we may call the postsecular turn consists in the notion that agency, or political subjectivity, is not mutually exclusive with spiritual values and that civic engagement as well as militant activism may involve significant amounts of spirituality. For as long as I believe in civic values such as justice, freedom, equality, and democratic criticism, I can be said to be a believer, albeit of the non-theistic kind. This provocative statement has an important corollary - namely that political agency need not be critical in the negative sense of oppositional and it need not rely on a dialectical scheme of production of countersubjectivities. This leads me to put the case for affirmative politics and to suggest that subjectivity is a monistic-process ontology of embodied and embedded - and hence situated - practices, through autopoiesis or self-styling. This view of the subject involves complex and continuous negotiations with others - human and non-human - and it therefore entails multiple forms of ethical accountability. We are confronted with a double challenge: firstly, we need to disengage subjectivity both from oppositional consciousness and from critique defined as negativity. Secondly, subjectivity needs to be linked to affects, to the imagination and transformative becoming, in ways that are perfectly compatible with postsecular spirituality.

Why can this argument be taken as provocative? Because a sort of secularist consensus has forged the practice of critical theory, installing a 
number of criteria and rules of intellectual behaviour that in due course have become set habits and canonical procedures. They rest on the antinomy reason-emotions, that is to say thinking-believing, which translates into other binary subsets: rational arguments versus acts of faith; public activity versus private beliefs; socio-political citizenship versus spiritual rituals; material versus spiritual; and, by extension, critical theory versus irrational factors such as spirituality (Asad et al., 2009).

The feminist movement was historically the first to seriously challenge the public-private distinction by proclaiming that the personal is the political. Feminists have also shown both the power structures that frame the separation of the public from the private and the many discrepancies and contradictions that characterize it. Feminism has a long and rich genealogy in terms of pleading for creative alternatives. From the very early days, Joan Kelly (1979) typified feminist theory as a double-edged vision, with a strong critical function and an equally strong creative function. Faith in the creative powers of the imagination is an integral part of feminists' appraisal of embodiment and the bodily roots of subjectivity.

The question of the public-private distinction raises also the issue of citizenship and of the role of women in the social contract (Pateman, 1988); it lies at the core of what Joan Scott has aptly labelled: 'sex-ularism' (Scott, 2007). The latter refers to the co-option of feminist and emancipatory politics into the neo-nationalist discourse of contemporary populist movements which claim exclusive rights to the legacy of Enlightenment secularism. In this respect, feminist theory and politics today cannot avoid a head-on collision with the very secularism that has historically been its point of reference (Braidotti, 2008). Mindful of this critical legacy, I want to argue that the postsecular predicament invites and somehow demands a reappraisal of the role of affective and even spiritual values at the core of the analytical tasks of critical theory. Let me develop this argument.

\section{Vital materialism, affect, ontology}

The residual spirituality at work in critical theory is best expressed in contemporary vital materialist thought (Braidotti, 2006, 2013) and in the 'affective turn' (Clough, 2008). They foreground the political impact of processes of becoming, defined as materially grounded transformative acts that reflect both the ontological relationality of the human subject and the social complexity of our network societies (Braidotti, 2011b). The return to vitalism, redefined through machinic autopoieses 
(Guattari, 1995), supplements the bio-political analysis of the age of intelligent machines (De Landa, 2002) and enables more accurate accounts of contemporary power in terms of vital politics.

This switch to vitalism is itself a symptom of the postsecular turn in political theory. Whereas classical vitalism is a flawed holistic notion, which became historically linked to the organicist philosophies of European fascism, contemporary vitalism is a philosophy of relations, flows, and assemblages. It moves beyond the fixity, the Eurocentric racism, and the sacralization of Life of nineteenth-century vitalism. ${ }^{1}$ Vital materialism presupposes and builds upon the philosophical monism that is central to a relational and non-unitary vision of subjectivity (Ansell Pearson, 1999; Grosz, 2004; Protevi, 2009; Patton, 2000; Braidotti, 2011a).

The core notion in both vital materialism and the affective turn is the autonomy of affect itself (Massumi, 2002). Psychoanalytic theory introduced this insight last century through the notion of desire and the primacy of unconscious processes. Lacan developed this into a fullfledged theory of the subject as built by Lack and Law. The psychoanalytic vision stresses that the subject is split, or 'di-vidual', and what divides it - but also constitutes it - is the linguistic signifier. Language as the mediator between self and the natural and social environment functions like a third party that separates the human subjects from the conditions that engendered them in the first place, namely the 'other'. In a patriarchal system, this 'other' is embodied and embedded institutionally in the maternal body. The task of splitting the native mother-child dyad is fulfilled by the Father. Therefore, the phallic Law-of-the-Father is not only the abstract master code of language, but also the key symbolic political rule in our social system, according to the isomorphism between the psychic and the social realms, which is central to psychoanalytic theory. The linguistic branch of poststructuralism sees language as the phallogocentric system (Derrida, 1978) and as the trace of an 'other' within (Kristeva, 1991), while its feminist critics see it as the master code of phallic patriarchal power (Irigaray, 1985; Cixous, 1976).

The political economy of domination and exclusion, which is institutionalized in language as a socio-symbolic system adds an extra dimension to the psychoanalytic vision of the 'di-vidual' subject. If language is both an ontological precondition and an ethical interpellation, then we are faced here with a seeming contradictory statement: that language, as an ontological $a$ priori, is external to the self, but it is also a constant presence at the heart of the self, thereby inscribing the relation to others as the defining feature of our common humanity. In the linguistic turn 
tradition, this is taken as a productive double bind: language has no object other than itself, but in so far as it is always tied to others, it is already quite a crowd. The writers - philosophers, critics, and poets have the obligation to deploy the analytical premises of language itself and to labour to share them with the readers. As Maurice Blanchot (2000) argued, dealing with language, in theoretical or poetical writing, entails the visualization of ethical relationality. In other words, the use of language in writing critical theory is a secular activity imbued with spirituality in so far as it both evokes and approximates the presence of the other.

These insights need to be read within the firmly secular structure of psychoanalytic thought. Psychoanalysis is a non-theological account of desire, passion, and affect, based on the Law of the Father and on the constitutive role of Lack. In this respect, Lacan differs from Freud who, as a champion of atheism and anti-clericalism, provided one of the most scathing analyses of the psychic function of religion in The Future of an Illusion (1927). The psychoanalytic approach consists in emphasizing the pathological aspects of the religious attitude, which is delusional at heart. Significantly, Freud includes a blind faith in the powers of scientific reason among these pathological formations and warns the scientific community against it. Diehard champions of atheism, like Dawkins (2006), would do well to heed this warning.

Linguistically based psychoanalysis recognizes the importance of affect but codes it negatively and defines the task of thinking as to both the yearning for and the mourning of the death of the Father as sociosymbolic carrier of Lack and Law. Psychoanalysis acknowledges both the constitutive and the unfulfillable character of the ethical demand made by the other which is inscribed as the heart of the split subject. The Law - both psychic and social - as well as psychoanalytic ethics consist in accepting this presence, while honouring the subject's unconscious desire. Ultimately, the psychoanalytic affect consists in enacting the destitution of the unitary subject and the end of the totality of truth and meaning, while acknowledging the enduring power of our individual and collective yearning for the very totality we lost.

The non-theistic spirituality of psychoanalytic theory is developed in interesting directions by Simon Critchley $(1999,2012,2013)$ who combines it with the philosophical work of Levinas (1969) and Derrida (2002). Building on their insights, Critchley argues that the subject is constitutionally split by the ethical demand by the other, which it can never fully meet. This 'demand' is an ethical interpellation that exceeds the subject's ability to fulfil it and yet constructs the subject around this 
impossibility. Critchley consequently stresses the importance of subject formation through negativity, not affinity or wonder. He believes in the relational nature of the subject but defines it in terms of the structural and constitutive function of the relationship to otherness. By extension he takes a stand against the ontology of vital politics, to which he opposes a pragmatic relationship to the real, messy world that calls both for oppositional politics and for the healing power of love.

There are significant differences between contemporary manifestations of affective relational ethics that continue to rely on social constructivist methods and monistic vitalism. Whereas a social constructivist approach within the linguistic turn tradition responds to this analysis oppositionally - in the case of Critchley, by returning to Gramsci (2012); in the case of Butler (2004), by appealing to Levinasian-inspired ethics; in the case of Derrida (1978), by advocating the open-ended and relational structure of language itself - vital materialism takes a different route. The nomadic subject is not linguistically ordained and therefore not subjected to the normative rules of Law and Lack. It rather expresses the vital, generative force of desire as the ontological drive by intelligent matter to express itself in as manifold a manner as it can sustain at any given point in space and time. Vital materialism is a practice of negotiations with the negative and of affirmation, not of negativity, and this fatal attraction for the positive constitutes not only its core ethical value but also its political ontology.

Under the impact of Spinozist monism, a different emphasis has been placed on the affective elements of human subjectivity under advanced capitalism and on the process of political subject formation. Rejecting the Lacanian conceptual structure and terminology, vital materialist thinkers stress the generative importance of affects and connect them to a positive view of desire as plenitude, not as Lack (Braidotti, 2006). The unconscious affects and drives, instead of being played back upon a sort of negative filter linked to the 'black box' of desire as Lack with its corollary of negative passions like envy, resentment, and perennial frustration, are approached affirmatively. Affects are the autonomous visceral elements of our allegedly rational and discursive belief system (Connolly, 1999). What they express is the profoundly relational nature of human subjectivity and its constitutive drive for the freedom of expression of its powers (potentia).

Vital materialism expresses the postsecular predicament in that it stresses a spiritual sense of intimacy with the world and a sense of entanglement in a web of ever-shifting relations and perpetual becoming. Bataille's agnostic spirituality is of great inspiration for nomadic thought in that it leads to a non-theistic form of naturalism that rejects 
all transcendental mystifications (Bataille, 1988). Mary Bryden calls it: 'a dynamism of the void' (Bryden, 2001: 5), which generates alternative visions of how matter and mind interact. Intimacy with the world speaks of our ability to recollect it and reconnect to it and hence of our capacity to find our 'homes' within it, in the pursuit of nomadic sustainable relations (Braidotti, 2006). Relational nomadic subjects engage in transversal connections - Haraway speaks of 'becoming-with' (Haraway, 2007) - multiple human and non-human others. Such webs of connections and negotiations define belonging not as attachment to static identity lines but as dynamic transversal moves across ecosophically interconnected categories. Relationality consists of a deep sense of negotiations with multiple ecologies - social, environmental, and psychic (Guattari, 1995) - that constitute us. A sense of familiarity with the world flows from the simple fact that we are the products of such ecological interconnections and notably of the nature-culture continuum (Haraway, 1997) that marks our era.

Theoretically and politically, vital materialism stands against the emphasis on political theology that, adapted from Carl Schmitt (1996), shaped the thinking of Leo Strauss and the American neo-cons through the Bush Jr years (Norton, 2004). The difference between the two approaches is that political theology in its classical enunciation as well as in the contemporary reinterpretation by Agamben (1998) reduces modern political theories to the secularized version of theological concepts. This fundamentally authoritarian reduction overemphasizes the ruthlessly dichotomous ('friend or enemy') and polarizing nature ('you are with us or against us') of the political relation. By stressing the antagonistic dimension as the defining core of politics (Mouffe, 2005), this theory ends up endorsing negativity and the necessity of violence. It also expresses an indictment of Western modernity and the democratic process as being structurally flawed.

Materialist vital ethics, on the other hand, while being resolutely atheistic, is ontologically pacifist. Deleuze's notion of the univocity of being and the immanence of matter is a vitalist anti-theology. Starting from the recognition of our intimacy with the world, it defends this claim on conceptual grounds by reference to a non-unitary subject immersed in the intelligent and self-organizing structure of life itself. It, therefore, infuses affect and endurance at the heart of its definition of materialism and of matter itself as a nature-culture continuum. The proposed methodology is not social constructivism, but rather neo-Spinozist expressionism (Braidotti, 2013). That is to say that events, phenomena, and subject formations are approached as actualizations of differential modes 
of becoming within a monistic universe. The univocity of being means that we have to deal with one matter, which is intelligent, embedded, embodied, and affective. It requires a subtler analysis of differential variations in the process of subjectivation in order to account for the actualization of transversal subject formations, also known as 'assemblages' (Deleuze and Guattari, 1987).

The Deleuzian position shares the same commitment to overturning the dialectical model of intersubjectivity as the linguistic tradition of semiotic, psychoanalysis, and deconstruction but takes a different road. It assumes the de-familiarization or relative de-territorialization of established values and habits of thought as a starting point to explore and experiment with alternative forms of subjectivity. This qualitative shift engages our collective imaginings (Lloyd and Gatens, 1999) and desire (Braidotti, 2011b) - in response to world-historical structural transformations. The nomadic subject is a materially embodied and historically embedded 'di-vidual' in that it is a bound instantiation of a common and ever-shifting matter. Each singular self is an actualized and temporarily bound expression of the ongoing process of becoming. Matter is intelligent and self-organizing; specific forms of individuation are carved out of this vital material, according to the monistic vision of matter. In the specific case of the human organism, it implies the embrainment of the body as well as the embodiment of the mind (Marks, 1998). It is a materialist non-theistic vital philosophy.

Spinoza is not the only philosopher Deleuze and Guattari enlist to the task of defining vital materialism. Nietzsche, Bergson, and Leibnitz also play a role as well as writers like Artaud, Melville, Kafka, Woolf, and Beckett. They are approached as spiritual thinkers of matter in that they combine a shared awareness of the death of God with renewed trust in 'the rebirth of immanence' (Ansell Pearson, 2001: 141). This entails a spiritual affirmation of joy, or life, as creation.

The renewed emphasis on immanence and on monism or the univocity of being is an affirmative response to Nietzsche's proclamation of the death of God. In a move that Dan Smith (2001) assesses as the most anti-Heideggerian moment in Deleuze's thought, vital materialist philosophy rejects the onto-theological paradigm (which, on the other hand, continues to haunt Derrida). Linking this move to the critique of the Lacanian notion of the Law as Lack, Deleuze and Guattari (1997) announce and explore the implications of the end of the judgement of God, the demise of the despotic power of the signifier, and the Oedipalized terror it exercises. They replace it with the joyful assertion of disobedience, anti-Oedipal disloyalty to the master, and lines of flight toward becoming-nomadic. 
We have here two radically different postsecular scenarios and two opposite views as to what constitutes the spiritual roots of this predicament and their political relevance. They differ considerably: I see the ethical vision of Otherness proposed by Levinas and Derrida as melancholy, fatalistic, and passive. Critchley's celebration of the aporetic as the political moment is, in my eyes, unethical, disguising its profound pessimism behind a thin veneer of tragic affectivity. Nomadic theory prefers to produce energizing affects and to look instead for the ways in which otherness prompts, mobilizes, and allows for flows of affirmation of values and forces which are not yet sustained by the current conditions. Critchley's position is moreover uncritically anthropocentric and closes off all relations to the non-human environment. Nomadic ethics, on the other hand, includes zoe-centred relations to external and nonhuman forces: cells (Franklin, 2007), viruses and bacteria (Parisi, 2004), and the planet as a whole (Haraway, 2007). All differences notwithstanding, however, we do also have a consensus about the relevance of a non-theistic spiritual dimension in critical theory and on its ethical and affective implications.

Another significant point of contrast between the two traditions of thought concerns the crucial importance of the imaginary (that is to say, of narrative and representations of social and cultural constructions), especially the emotional and visual impact of totemic and iconic figures as fundamental structures of psychic order and social cohesion. This emphasis on the imaginary rests conceptually on the isomorphism between psychic and social structures, which in Lacanian psychoanalysis, as I argued before, are equally subjected to the rule of the Master signifier and of desire as Lack.

Psychoanalysis offers important insights into the crucial role played by the social imaginary and its unconscious interpellations. It does so, however, within a social constructivist approach that privileges the structural importance of the social and psychic codes that implement the phallic Law. Thus, imaginary representations fulfil both a psychic and a social function, fuelling the powers of identification with dominant icons. If in the past these icons were religious in origin and function, today they are dominated by popular culture images and by political figures, ranging from the ubiquitous face of Che Guevara or the young Angela Davis, to the images of Nelson Mandela and other secular saints like Princess Diana. These iconic representations fulfil a totemic function in the sacrificial sense of the term: 'they suffered so that we may be better off'. The irrational and even 'mystical' elements of mass popular culture have been commented upon - mostly negatively - by 
critical theorists as diverse as Adorno and Horkheimer, and Deleuze and Guattari. Contemporary digital techno-culture has intensified this trend, encouraging viral links between visual culture, the faces of global icons, and a postsecular social imaginary that fetishizes them into the 'sacred monsters' of global consumption. An opportunistic and profitdriven pseudo-spirituality is therefore integrated into the cultural logic of advanced capitalism. It is marketed by visually driven popular culture, which both sacralizes and cannibalizes a fast turnover of icons.

Deleuze goes further than psychoanalysis and offers a different theory of the social imaginary, arguing productively against the primacy of linguistic process of signification. The imaginary is not the emanation of a symbolic system that allegedly structures both our psychic and our social existence, but rather the material implementation of social relations of power. Accordingly, Levinas's emphasis on transcendence and on the face as the ethical boundary of the other (Levinas, 1999) is explicitly critiqued by Deleuze and Guattari. The face is for nomadic thought a decoding and over-coding machine fully inscribed in the market economy and in despotic power relations. Faces produce representational codes and practices - a surplus value function which Deleuze analyses in terms of the immanence of power and the notion of 'faciality $^{2}$ (Deleuze and Guattari, 1987). This function is made manifest in the market economy through the process of hyper-individualistic branding of the faces of celebrities and the overwhelming role they play in the construction of the collective cultural imaginary. The theoretical advantage of this approach is the ability to account for the fluid and contradictory workings of power in advanced capitalism by grounding them in immanent relations and hence resisting them by the same means.

\section{Affirmative politics}

I have argued so far that the residual spirituality of psychoanalytic theory consists in highlighting the affective dimension of subject formation in three interrelated ways. Firstly, through the sober and non-theistic acknowledgement of the importance and the autonomy of affects and desire. Secondly, by stressing the constitutive role played by the ethical demand of the other in constructing subjectivity. Thirdly, by exploring the role of the imaginary as visual recognition of the (face of the) other and the social significance of iconic images. On all three counts the affective turn introduced by psychoanalysis is a major element in the postsecular predicament and it paves the way for the further developments proposed by vital materialism. 
The major point of difference between this tradition and Deleuze is paradigmatic and it corresponds to the switch from Hegel to Spinoza I mentioned at the beginning. Psychoanalysis incorporates and perpetuates a negative Hegelian vision of desire as Lack and a dialectical understanding of the self-other opposition in the constitution of the subject. Whatever spiritual dimension may be at work in psychoanalysis, it bears a privileged bond to negativity. Spinoza-based vital materialism on the other hand takes a firm stand against this tradition of thought and proposes an alternative based on Spinozist monism and the idea of desire as plenitude and the expression of freedom. The postsecular spiritual dimension here entails the notions of the monistic univocity of being, or radical immanence, positivity, and the productivity of desire. Affirmative politics challenges the traditional equation between political subjectivity and critical oppositional consciousness and the reduction of both to negativity. What this means is that the political cannot be assumed to equate the rational, or the public sphere, and that the spiritual is not the same as the irrational, or the private sphere. We need more dynamic and porous demarcation lines between these domains; I will start by discussing political subjectivity.

Deleuze and Guattari diversify political subjectivity along multiple axes, each of which spells a different location in space and time. Standard oppositional politics is advocated, in a post-Foucauldian mode, as a necessary form of resistance to the social manifestations of injustices, violence, and oppression. This kind of political intervention also labelled as 'la politique', or politics as usual - is postulated on the temporal axis of Chronos, linear institutional time. This political stance acknowledges human vulnerability, on the one hand, and despotic power relations, on the other.

The political - or 'le politique' - on the other hand, is postulated on the axis of Aion - the non-institutionalized time of becoming and of affirmative critical practice. It is minoritarian and it aims at the counteractualization of alternative states of affairs in relation to the present. Based on the principle that we do not know what a body can do, the becoming-political ultimately aims at transformations in the very structures of subjectivity. It is about engendering and sustaining processes of 'becoming-minoritarian'. This specific sensibility combines a strong historical memory with consciousness and the desire for resistance. It rejects the sanctimonious, dogmatic tone of dominant ideologies, left or right of the political spectrum, in favour of a production of affirmative acts of transformation. The creative aspects of this practice combine with a profound form of asceticism; that is to say, with an ethics of non-profit 
to build upon micro-political instances of activism, avoiding overarching generalizations or new master discourses (Lyotard, 1984). This humble yet experimental approach to changing our collective modes of relation to the environment, social and other, our cultural norms and values, our social imaginary, our bodies, ourselves, is the most pragmatic manifestation of the politics of radical immanence.

This distinction between politics and the political is relevant to discussions of the postsecular predicament. In the work of Michel Foucault, it is postulated along the double axis of power as restrictive or coercive (potestas) and as empowering and productive (potentia). The former focuses on the management of civil society and its institutions, the latter on the transformative experimentation with new arts of existence and ethical relations. Politics is made of progressive emancipatory measures predicated on chronological continuity, whereas the political is the radical self-styling that requires the circular time of critical praxis. Critical theory consists in connecting thinking not so much to 'la politique' (organized or majoritarian politics) as to 'le politique' (the political movement in its diffuse, nomadic, and rhizomic forms of becoming). Thinking is about the creation of new concepts as navigational tools or 'conceptual personae' that can assist us in negotiating temporary analytical frames to capture complexity in its manifold manifestations.

The political is the shared acknowledgement of ethical relationality and it is postulated upon Spinozist monism (Macherey, 2011) and the rejection of the legacy of Hegelian-Marxist dialectics of consciousness and otherness. This school of critical theory banks on negativity and in a perverse way even requires it, because it builds on the assumption that the critical position consists in analysing negative social and discursive condition in order to better overthrow them. In other words it is the same conditions that construct the negative moment - for instance, the experience of oppression, marginality, injury, or trauma - and also the possibility of overturning them. The same analytic premises provide both the damages and the possibility of positive resistance, counteraction, or transcendence (Foucault, 1977a; Brown, 2006). What triggers and, at the same time, is engendered by this process of both analysis and resistance is called 'oppositional consciousness'. In other words, the negative experience can be turned into the matter that critical theory engages with and thus into the productive source of counter-truths and values, which aim at overthrowing not only the real-life negative instances but also their representations.

This process has become canonized as the equation of critical political subjectivity with negativity, oppositional, or, in Hegel's terms from 
Phenomenology of Spirit, the 'unhappy' consciousness (Hegel, 1977: §230). As an alternative, I want to suggest a non-Hegelian, monistic, and vitalmaterialist analysis that foregrounds the relational, negotiation-bound, and affirmative elements of this process. My point is that the political as 'le politique' - is defined by a relational, affirmative ethics that aims to cultivate and produce the condition of its own expression: it is a praxis based on a positive definition of the subject and process-driven, relational 'di-vidual'. This assumes that a subject's ethical core is clearly not his/her moral intentionality, as much as the effects of power (as repressive - potestas - and positive - potentia) his/her actions are likely to have upon the world. It is a process of engendering empowering modes of becoming (Deleuze, 1990; Braidotti, 2006).

Here is the punchline of contemporary vital-materialist politics: given that the ethical good is equated with radical relationality aiming at affirmative empowerment, the ethical ideal is to increase one's ability to enter into modes of relation with multiple others. Oppositional consciousness is replaced by affirmative praxis; political subjectivity is a process or assemblage that actualizes this ethical propensity. The view of subjectivity I have been arguing for does not condition the emergence of the subject on negation but on creative affirmation; not on loss but on vital generative forces. The propensity for affirmation is a key feature of neo-Spinozist nomadic subjects and it explicitly acknowledges its residual spiritual connotations. Affirmation is the key ethical value for the postsecular turn in critical theory, which imagines a subject whose existence, ethics, and politics are not indexed on negativity but on production of affirmative affects.

The rejection of the dialectical scheme implies also a shift of temporal gears. It means that the conditions for political and ethical agency are not dependent on the current state of the terrain: they are not oppositional and thus not tied to the present by negation. Instead, they are projected across time as affirmative praxis, geared to creating empowering relations aimed at possible futures. Ethical relations create possible worlds by mobilizing resources that have been left untapped in the present, including our desires and imagination. They are the driving forces that concretize in actual, material relations and can, thus, constitute a network, web, or rhizome of interconnection with others.

Such a vision, moreover, does not restrict the ethical instance within the limits of human otherness, but also opens it up to interrelations with non-human, post-human, and inhuman forces. The eco-philosophical dimension is essential to the postsecular turn in that it values one's reliance on the multiple ecologies that sustain us in a nature-culture 
continuum (Haraway, 1997; Guattari, 1995, 2000) and within which subjects must cultivate affirmative ethical relations. Critical theory is rather about strategies of actualization of affirmation as an ethical practice that consists of multiple micro-political practices of daily activism or interventions in and on the world we inhabit for ourselves and for future generations.

The essence of my argument is that there is no logical necessity to link political subjectivity to oppositional consciousness and reduce critique to negativity. Critical theory can be just as critical and more persuasively theoretical if it embraces philosophical monism and vital politics and disengages the process of consciousness-raising from the logic of negativity, connecting it instead to creative affirmation. The corollary of this shift is twofold: firstly, it proves that political subjectivity or agency need not be aimed solely at the production of radical counter-subjectivities. It is not a social constructivist oppositional strategy that aims at storming the Bastille of capitalism, or undoing the winter palace of phallogocentrism. It rather involves discontinuous and heterogeneous negotiations with dominant norms and technologies of the self. Secondly, it argues that political subjectivity rests on a postsecular ethics of otherness that values reciprocity as mutual specification or creation. It does not pursue the recognition of sameness, but rather the quest for creative alternatives and sustainable futures.

This position is postsecular in the sense that it actively works towards the creation of affirmative alternatives by working through the negative instances, including their representations. This shift is central to the postsecular turn in critical theory, which imagines a subject whose existence, ethics, and politics are not indexed on negativity and hence on the horizon of alterity and melancholia. This subject is looking for the ways in which otherness prompts, mobilizes, and allows for the affirmation of what is not yet contained in the present conditions, namely sustainable futures.

\section{Postsecular spirituality}

The emphasis on affirmation, desire as plenitude, and consequently the creation of possible futures is one of the key aspects of the residual spirituality in critical theory. For instance, the system of feminist civic values rests on a social notion of faith in progress as the hope for the construction of alternative social horizons, new norms, and values. Faith in progress itself is a vote of confidence in the future. Ultimately, it is a belief in the perfectibility of Wo/Man, albeit it in a much grounded, 
accountable mode that privileges partial perspectives (Haraway, 1988). It is a postsecular position, in that it is an immanent, not transcendental theory, which posits generous bonds of cosmopolitanism, solidarity, and community across locations and generations. It expresses sizable doses of residual spirituality in its yearning for social justice and sustainability.

At some level, postsecular spirituality has all the appearance of a logical paradox, which conceals deeper levels of complexity. We are confronting today a postsecular realization that all beliefs - their different propositional contents notwithstanding - are acts of faith. The operational concept is faith itself; that is to say, the belief in a social narrative, in its imaginary hold, and its normative implications. All belief systems contain a hard core of narrative normativity and of spiritual hope. Nietzsche put it with customary wit: if you believe in grammar, you believe in God $^{3}$ (Kauffman, 1982).

To which I am tempted to reply that God is dead, Marx is dead, and I am not feeling too well myself, ${ }^{4}$ so the very scaffolding of contemporary belief systems is rather shaky. Postsecular subjects today are at best believers without belief systems. This is not a crisis, however, but the opening of multiple possibilities. The vital-materialist vision of the subject speaks to and of a post-Nietzschean world without monotheistic faith. A world without Lack and Law, free from the role of judgement defined as the expression of the negative and despotic face of power (potestas). It is the universe of Kafka and Beckett, re-read with Deleuze: a world that has exhausted all faith in traditional values and eschatological vision of the future, to seek for transformative energy in the immanence of a continuous present. This world has worked through the powers of icons and magical thinking, it has sobered up after the transcendentalist delirium, and has landed here and now in the humble reality of just a life, just a continuous present that never forgets the future.

Ontological monism and Spinozist ethics are often criticized as aristocratic, detached from the contingencies of real life and potentially authoritarian in political terms (Hallward, 2006). I, as most Deleuzians, on the other hand, praise the ontological pacifism and non-violence of vital materialism. The awareness of ontological relationality is neither elitist, nor naïve. It does not exclude the awareness of negative relations and destructive affects. Elsewhere I have outlined the frame of a nomadic vital ethics that consists in the praxis of actively constructing conditions and relations conducive to affirmation (Braidotti, 2006). The ethical good is a praxis, not a given. It is the collective pursuit of social relations aiming at constructing affirmative values and practices. 
The argument for postsecular spirituality draws strength from the politics of global consumption of Life itself today and redesigns the relation to otherness within its opportunistic political economy. We need to attend to the forces of life and matter that are traversed by and not exhausted by 'politics as usual'. This implies giving centre stage to the vital materialism of zoe as multiple relations or flows of interaction, production or generative power of the inhuman. This has two major implications. The first one is ethical: we need to rethink responsibility in terms of eco-philosophical principles. A diffuse sort of ontological gratitude is needed in the post-human era, towards the multitude of non-human agents that is supporting us through the present anthropological mutation. Bio-centred egalitarianism aims instead at dispersing and transcending anthropocentrism by dissolving it into a network of bio-agencies and eco-sophical relations. This is not techno-paganism but radical immanence in its ethical version, its most concrete form: it points to the becoming-imperceptible of the former anthropocentric subject. I will return to this issue.

The second implication is political: we need to organize communities that reflect and enhance this vision of the subject. This is a community that acknowledges difference as the principle of non-Oneness as its founding myth of origin - anti-Oedipal, post-humanist, vitalist, nonunitary, and yet accountable. Not bound together by the guilt of shared violence, or irreparable loss, or unpayable ontological debts - but rather by the compassionate acknowledgement of our common need to negotiate thresholds on sustainability with and alongside the relentless and monstrous energy of a 'Life' that does not respond to our names. A political economy of non-compensation needs to be installed - that is to say, a fundamental principle of non-profit. This rejects the liberal vision of the subject, which inscribes the political economy of capitalism at the heart of subjectivity in terms of losses, perpetual debt, savings, recognition, and production. Moreover, it moves further than the histrionic post-psychoanalytic quip about the trappings of the surplus value of jouissance (Žižek, 2013). Acknowledging instead the importance of proximity and relation, it turns the margins of unspeakable-ness, the traumatized nature of our being-in-the-world and our shared fragility into the praxis of co-construction of affirmative social practices. It is an affirmative approach to the tragedy of 'existence in a worldly universe that lacks all guarantees' (Gourgouris, 2013: 23). It is a form of amor fati, a way of living up to the intensities of life, so as to be worthy of all that happens to us - to live out our shared capacity to affect and to be affected. 
Postsecular spirituality is the unspectacular, humble acknowledgement of ontological relationality, which assumes the monistic ontology and the nature-culture continuum. It consequently involves eco-sophical interrelations of the non-theistic but vital kind with both human and non-human others. Postsecular spirituality, redefined as a topology of affects and affirmative ethics, is one of the attributes of nomadic subjectivity and it designs an ethics of affirmation and an eco-philosophy of relations. The process of unfolding affects is central to the composition of radically immanent bodies and thus it can be seen as the actualization of enfleshed materialism within a monistic ontology. The selection of the forces of becoming is regulated by an ethics of joy and affirmation, which functions through the transformation of negative into positive passions. These are essentially a matter of affinity: being able to enter a relation with another entity whose elements appeal to one produces a joyful encounter. They express one's empowerment as potentia and increase the subject's capacity to enter into further relations, grow, and expand. This expansion is time-bound: the nomadic subject by expressing and increasing its positive passions empowers itself to last, to endure, to continue through, and in time defined as Aion, not as Chronos. This is the politics of becoming: a collective assemblage of forces that coalesce around commonly shared elements, webs of sustainable interconnections that empower us to grow and to endure.

\section{Ways of dying}

Spiritual practices are embodied and embedded, active and affective. They do not take place in a fight from the flesh but through it. I want to take this a step further and argue that nomadic subjectivity as radical immanence implies a practice of postsecular spirituality which also redesigns the idea and the experience of death (Braidotti, 2006). Whereas psychoanalysis indexes the unconscious libidinal processes in the allpowerful death drive, whose entropic force is central to human desire (Laplanche, 1976), nomadic materialism offers a vital vision of death.

Conceptually, death has to do with the ultimate phase of the process of becoming, according to Deleuze and Guattari, namely becoming-imperceptible, in keeping with the deep materialism of my Spinozist roots. What we humans truly desire as humans is to disappear, to step on the side of life and let it flow by, without actually stopping it. What we really aspire to is to self-style our own death (Phillips, 1999). Our fundamental drive (conatus) is to express the potency of life (potentia), by joining forces with other flows of becoming. The great animal-machine, the 'chaosmosis' (Guattari, 1995) of the universe is the horizon of becoming 
that marks the resilience of life as bios/zoe and its generative power also through what we usually call death.

Death is our becoming-imperceptible. That is the point of fusion between the self and his/her habitat, the cosmos as a whole. It marks the point of evanescence of the self and its replacement by a living nexus of multiple interconnections that empower not the self, but the collective; not identity, but affirmative subjectivity; not consciousness, but affirmative interconnections. The distinction Deleuze draws from Spinoza and Blanchot - the distinction between personal and impersonal death - is relevant here (Deleuze, 1983, 1990, 1995). Personal death of the self as social identity is the suppression of the individualized ego. Impersonal death, on the other hand, is beyond the ego: a death that marks the extreme threshold of my powers to become.

Impersonal death is the incorporeal or intensive event that opens up a proliferation of generative options of a qualitative different kind. The becoming-corpse of the body is another phase in the impersonal Life of the species. What matters is the ethical or intensive Life, which is ascetically lived as virtual suicide in the pursuit of the destitution of the unitary self. Ultimately, all one has left is what one is propelled by, namely affects, relations, and becoming. One is constructed in these transitions and through these encounters. Impersonal death is the ultimate destitution of selfhood into embodied and embedded relations, that is to say, into radical immanence.

As I argued elsewhere (Braidotti, 2006), death is the inhuman conceptual excess: the unrepresentable, the unthinkable, and the unproductive black hole that we all fear. Yet, death is also a creative synthesis of flows, energies, and perpetual becoming. Because humans are mortal, death, or the transience of life, is written at our core: it is the event that structures our time-lines and frames our time-zones, not as a limit but as a porous threshold. In so far as it is ever-present in our psychic and somatic landscapes, as the event that has always already happened (Blanchot, 2000), death as a constitutive event is behind us, it has already taken place as a virtual potential that constructs our inscription into Time, which is the other matter Life is made of. The temporality of death is time itself, by which I mean the totality of time.

The full blast of the awareness of the transitory nature of all that lives is the defining moment in our existence. It structures our becoming-subjects, our capacity and powers of relation, and the process of acquiring ethical awareness. Being mortal, we all are 'have beens': the spectacle of our death is written obliquely into the script of our temporality, not as a barrier but as a condition of possibility. This death 
that pertains to a past that is forever present is not individual but impersonal; it is the precondition of our existence, of the future.

This proximity to death is a close and intimate friendship that calls for endurance, in the double sense of temporal duration or continuity and spatial suffering or sustainability. As an individual occurrence, it will come in the form of the physical extinction of the body; but as impersonal event, in the sense of the awareness of finitude, of the interrupted flow of my being there, death has already taken place. We are all synchronized with death - death is the same thing as the time of our living, in so far as we all live on borrowed time. Making friends with the impersonal necessity of death is an ethical way of installing oneself in life as a transient, slightly wounded visitor. We build our house on the crack, so to speak. We live to recover from the shocking awareness that this game is over even before it started. The proximity to death suspends life, not into transcendence, but rather into the radical immanence of 'just a life' (Deleuze, 1995), here and now, for as long as we can and as much as we can take. It is indeed the case that the Life in me will go, but it is zoe, not the rational conscious, sovereign individual, without a 'self' that could even claim to supervise, let alone control the process. Life does go on, as zoe always does; so much so that the injunction is not the classical 'give me life (bios) or give me death', but rather 'give me life (zoe) and hence give me death'.

This does not mean, however, that Life unfolds on the horizon of death. This classical notion is central to the metaphysics of finitude that, especially in the Heideggerian tradition, sacralizes death as the defining feature of human consciousness (Agamben, 1998). I want to stress instead the productive differential nature of zoe, which means the productive aspect of the life-death continuum. It does not deny the reality of loss, but rather to re-work it so as to assert the vital powers of healing and compassion. This is the core of post-human affirmative ethics in a contemporary Spinozist mode (Braidotti, 2011b). Nomadic processes of becoming-imperceptible lean towards a spirituality, which is the opposite of mysticism in the sentimental mode dear to Christianity, and definitely not a stepping stone to the final redemption. It is not a morality of fringe benefits, but rather an ethics of non-profit that points beyond metaphysical life insurance politics. It enjoys gratuitous acts of kindness in the mode of a becoming-world of the subject.

'Becoming-imperceptible' is a way of configuring the transmutation of values which propels us out of the black hole of critical negativity into the paradoxically generative void of positivity, or full affirmation. It is a seduction into life that breaks with the spectral economy of the eternal 
return of the Same, and involves friendship with impersonal death. At that point of becoming-imperceptible, all a subject can do is mark his/ her assent to the loss of identity (defined as a by-product of potestas) and respectfully merge with the process of potentia itself, and hence with one's environment. It is the absolute form of de-territorialization and its horizon is beyond the immediacy of life.

\section{Conclusion: of possible futures}

The core of postsecular spirituality is programmatic and forwardlooking. This volume has been conceived very much in this spirit and as an affirmative contribution to this ongoing social and symbolic project. The authors gathered here agree that we need new cosmologies and world views that are appropriate to our own high level of complexity and the technological development and to the ferocious and insidious sets of structural injustices and violent modes of dispossession that mark the global economy. We need original cultural, spiritual, ethical creativity, be it myths, narratives, or representations that are adequate to this new civilization we inhabit (Haraway, 1997).

This project requires more visionary power or prophetic energy, qualities which are neither especially in fashion in critical theory academic circles, nor highly valued in these times of commercial globalization. This combination of sensitivity to representational issues and awareness of the materialist workings of power is the force of critical intellectuals (West, 1994). More conceptual creativity and theoretical courage are needed in order to confront the challenges of the global era. Creativity is unimaginable without some visionary or spiritual fuel.

Prophetic or visionary minds are thinkers of the future. The future as an active object of desire propels us forth and we can draw from it the strength and motivation to be active in the here and now of the present. The present is always the future present: it will have made a positive difference in the world. Only the yearning for sustainable futures can construct a liveable present. The anticipation of endurance, of making it to a possible 'tomorrow', transposes energies from the future back into the present. This is a non-entropic model of energy flow and hence of transferral of desire as creative becoming. This is not a leap of faith, but an active transposition, a transformation at the in-depth level, a praxis that enacts a change of critical culture, also at the ethical level. As Deleuze put it: we need both a future and a people.

A prophetic or visionary dimension is necessary for critical theory to secure the one element that advanced capitalism is systematically 
depriving us of, namely, sustainable transformations. The propositional core of the postsecular predicament takes a stand against the cynicism of neo-Marxists and the nostalgia of neo-Hegelians, with their perpetual infatuation with violence, antagonism, and confrontation, against the sterility of the vision of critique as the work of negativity. The residual spirituality of critical theory resides in acknowledging that we need to actually dare take the risk of affirmative politics and the collective construction of social horizons of hope. A qualitative and creative leap induced by a prophetic, visionary dimension is a way to repair and compensate for that which we are running out of: time.

\section{Notes}

With thanks to Tobjn de Graauw and Ernst van den Hemel for their constructive comments.

1. In this respect, I concur with Foucault's claim that Deleuze and Guattari's project of Capitalism and Schizophrenia is an introduction to anti-fascism and to non-fascist ethics (Foucault, 1977b).

2. Faciality is the function of re-territorialization of the subject. It consists in branding the self as the private property of the capitalist individual, so as to make it recognizable, consumable, and profitable.

3. Ernst van den Hemel pointed out to me the exact quote: 'I am afraid we are not rid of God because we still have faith in grammar' ( Kaufmann, 1982: 483). Deleuze cites it in The Logic of Sense (1990: 281): 'Nietzsche's predictions about the link between God and grammar has been realized.'

4. This is the text of a graffiti I read on the walls of Paris in the 1980s.

\section{References}

Agamben, G. (1998). Homo Sacer: Sovereign Power and Bare Life. Standford, CA: Stanford University Press.

Ansell Pearson, K. (1999). Germinal Life. The Difference and Repetition of Deleuze. London and New York: Routledge.

Ansell Pearson, K. (2001). 'Pure Reserve: Deleuze, Philosophy and Immanence.' In M. Bryden (ed.) Deleuze and Religion. New York and London: Routledge.

Asad, T., Brown, W., Butler, J. and Mahmood, S. (2009). Is Critique Secular? Blasphemy, Injury and Free Speech. Berkeley: UC Press.

Bataille, G. (1988). The Accursed Share. New York: Zone Books.

Blanchot, M. (2000). The Instant of My Death. Stanford, CA: Stanford University Press.

Braidotti, R. (2006). Transpositions. On Nomadic Ethics. Cambridge: Polity Press

Braidotti, R. (2008). 'In Spite of the Times: The Postsecular Turn in Feminism.' Theory, Culture \& Society 25(6), 1-24.

Braidotti, R. (2011a). Nomadic Subjects: Embodiment and Sexual Difference in Contemporary Feminist Theory, 2nd edition. New York: Columbia University Press. 